Shala BarczewsKa

Jan Kochanowski University, Kielce

\title{
TRANSFORMING POST-COMMUNIST SOCIETIES: THE THIN LINE BETWEEN CULTURAL COMPETENCIES AND CULTURAL VALUES
}



he collapse of communism in Central and Eastern Europe dropped employees who had been raised under one set of cultural norms and values into a new system with an unfamiliar set of norms and values and expected to assimilate. When Solidarity leader Lech Wałęsa stated that his plan for post-communist Poland was to look to "the normal, well-tested solutions" of private entrepreneurship, the market, pluralism, and parliamentary democracy, ${ }^{1}$ he was describing a goal, but not the path leading to its fulfilment. Wałęsa was looking at Western institutions, but those forms did not match social and political realities. ${ }^{2}$

Sociologist Piotr Sztompka refers to this disparity between cultural values developed under real socialism and the new norms and values required under capitalism as a gap in cultural competence. ${ }^{3}$ Although, it is agreed that the work ethic and employment strategy developed under communism is incompatible with free-market capitalism, there are two problems with a dismissive "just follow the West" solution. Firstly, cultural values run deep, making "eradication"

${ }^{1}$ Quoted in P. Sztompka, "The intangibles and imponderables of the transition to democracy," Studies in Comparative Communism, 24:3, 1991.

2 G. Schöpflin, "Post-communism: construction new democracies in Central Europe," International Affairs, 67:2, 1991.

3 P. Sztompka, "Civilizational Competence: A Prerequisite of Post-Communist Transition," in: Papers from participating universities in Bulgaria, Czechoslovakia, Hungary, Poland, Romania, and the United States of America. Cracow, 8-12 November 1992, Knoxville, Tennessee: The University of Tennessee, 1993. http://www.friends-partners.org/newfriends/ audem/audem92/Sztompka.html. See also: G. Hofstede, Cultures and Organizations: Software of the Mind, Maidenhead, UK: McGraw-Hill, 1991. 
of "communist residue" from "human personalities and [...] most importantly, from the underlying cultural structures", a difficult task. ${ }^{4}$

Secondly, "follow the West" is not a clear model. A cursory glance at literature on international business cultures shows that management styles and employee behaviour differ between capitalist countries. ${ }^{5}$ Thus, the simple adoption of Walesa's "well tested solutions" does little to designate the cultural values that would have to change for Poland, or other post-communist societies, to become successful market competitors. In order to understand the difference between unhealthy residues of communism and the "normal'" cultural values of Central and Eastern European societies, research into cultural values systems is necessary. Unfortunately, studies to date on cultural values in these countries is lacking, especially in comparison to those conducted in Europe and East Asia.

This paper juxtaposes the cultural value dimensions suggested by Frons Trompenaars and Hampden-Turner with Sztompka's prerequisites for civilizational competences. ${ }^{6}$ The results and their implications are discussed at the end of this paper.

\section{Defining culture and cultural values}

A distinction can be made between two different concepts of culture: culture one and culture two. Hofstede describes culture one as what is usually understood by culture in Western language: "civilization" or "refinement of the mind." It also includes the "results of such refinement, like education, art, and literature." Culture two refers to a wider concept common among social scientists; it includes both aspects of culture one and aspects of daily life such as "greeting, eating, showing or not showing feelings, keeping a certain physical distance from others, making love, or maintaining body hygiene."

4 P. Sztompka, "The intangibles and imponderables of the transition to democracy," 297.

5 E.g., E. T. Hall and M. Hall, Understanding cultural differences, Yarmouth: Intercultural, 1990; F. Trompenaars, Riding the waves of culture. Understanding cultural diversity in business, 2 ed., London: Nicholas Brealey Publishing, 2002.

${ }^{6}$ Ch. Hampden-Turner and F. Trompenaars, Building cross-cultural competence. How to create wealth from conflicting values, New York: John Wiley \& Sons, 2002; F. Trompenaars, Riding the waves of culture; Sztompka, "Civilizational Competence: A Prerequisite of Post-Communist Transition."

7 G. H. Hofstede, Cultures and organizations. Software of the mind, New York, London: McGraw-Hill, [1991] 1997, 6-7. 
Hofstede illustrates his concept of culture with a set of concentric rings. Items that are external or explicit are in the outer rings with deeper or implicit values at the core. Fons Trompenaars and Charles Hampden-Turner, who see themselves as extending and developing Hofstede's research, begin with the same distinction between culture one and culture two, but make some important adjustments. Firstly, they title the core of their diagram assumptions about existence. Secondly, Trompenaars and Hampden-Turner begin with three types of dilemmas or relationships around which each culture is organized: relationships with people, with time, and with nature. From these, they identify seven categories by which cultural differences are defined and organized. ${ }^{8}$ Because of its dynamic nature, Trompenaars and Hampden-Turner's cultural dimensions were chosen for comparison with Sztompka's competencies.

\section{Relationships with people:}

(1) Universalism / Particularism

Is integrity expressed through loyalty to universal laws, even when it costs friendship, or particular relationships, even if that means bending the rules??

(2) Communitarianism / Individualism

Is the greater good reached through sacrificing for the community or by promoting individual advancement? ${ }^{10}$

(3) Neutral / Affective (Emotional)

Should a person express emotions in the business setting or is more success achieved by maintaining a neutral posture? ${ }^{11}$

(4) Diffuse / Specific

Are different aspects of life viewed as part of one diffuse whole or is it compartmentalized into specific segments? ${ }^{12}$

8 For a summary of different cultural value orientations see F. Trompenaars, Riding the waves of culture, 8-10. Summaries of all culture values can also be found in other works by the authors, such as Ch. Hampden-Turner and F. Trompenaars, Building cross-cultural competence. For simplicity page numbers are provided from Riding the waves of culture.

9 F. Trompenaars, Riding the waves of culture, 29-49.

10 Ibidem, 50-68.

11 Ibidem, 69-80.

12 Ibidem, 81-101. 
(5) Achievement / Ascriptive

Is status achieved through demonstrating one's abilities or is it ascribed by the society depending on inherent characteristics such as family and age? ${ }^{13}$

\section{Relationship with the environment:}

(6) Inward / Outward

Does a person create his own destiny by utilizing what he finds inside himself or does he try to go along with the flow of life directed by outside forces? ${ }^{\text {?4 }}$

\section{Relationship with time: $:^{15}$}

(7) Sequential / Synchronic ${ }^{16}$

Is life viewed as a series of sequential events along a line or do events happen synchronically, overlapping and repeating themselves in a circular fashion?

(8) Past-, Present-, or Future- Orientation ${ }^{17}$

When making decisions, is the focus on the past and tradition, present 'impact and style' or potential future opportunities and benefit? Who in society is most valued: previous generations, one's own generation, or the next generation?

The authors advise that it is better to look at these apparently opposite values as mirror reflections of one another; they both can add value to a society, but they can each also be taken to a dangerous extreme. Racism, fascism, materialism, communism, and many other '-isms' that have precipitated suffering, injustice, and warfare are the result of taking one or More Of These Values To The Extreme.

\section{Legacies of communism and civilizational competence}

Citizens of post-communist Poland were left to adapt to this new reality by picking and choosing what they saw to be the best "well tested solutions" of democratic, capitalist countries and imitating them. However, imitation rarely

13 Ibidem, 102-119.

${ }^{14}$ Ibidem, 141-156.

15 For the purposes of this research project, relationship to time was subdivided into these two aspects.

16 Ibidem, 120-140.

17 Ibidem, 138-139. 
brings about real societal change. Real, enduring change can only take place when the cultural values of a society change along with its practices, and values are much deeper, and thus slower to change, than external activities. ${ }^{18}$

The values encouraged and supported under the communist regime in Poland politicised the work environment and discouraged Western entrepreneurial skills. Subsequently, people lost the sense of individual responsibility normally present with industrialization. When the system finally did collapse, it was difficult for individuals to learn to take responsibility for their actions leading to a symptom referred to as "learned helplessness." 19

However, not all Polish cultural attitudes can be attributed to communism. Ivan Volgyes aptly asks if it is possible to "discern whether it is the communist value structure or the previously existing one that can be regarded as the independent variable determining current behaviour." ${ }^{20}$ Schwartz and Bardi identify religion and the state of the country before World War II as possible influences. ${ }^{21}$ In Poland, this would translate to mean the role of the Roman Catholic Church, an authoritarian and often foreign ruler, and an agrarian economy. Another aspect of Polish history worth considering is Poland's relatively late (post-WWI) attempts at modernization. George Schöpflin claims that elites tried to create a modern European nation after WWI by importing Western institutions; however, the attempt largely failed due to a lack of mutual trust between the elite rulers and those they ruled. ${ }^{22}$

18 G. Schöpflin, "Post-communism: construction new democracies in Central Europe."

19 J. L. Curry, "The Sociological Legacies of Communism," in: The Legacies of Communism in Eastern Europe, ed. Z. Barany and I. Volgyes, Baltimore: Johns Hopkins University Press, 1995, 55-83; J. Kochanowicz, "Incomplete Demise. Reflections on the Welfare State in Poland after Communism," Social Research, 64:4, 1997. For further information on 'learned helplessness' see H. Grzymała-Moszczyńska, "Unlearning Learned Helplessness: The view from Poland," Christian Century 111, 1994.

${ }^{20}$ I. Volgyes, "Legacies of Communism. An Introductory Essay," in: The Legacies of Communism in Eastern Europe, ed. Z. Barany and I. Volgyes, Baltimore: Johns Hopkins University Press, 1995, 1-22. See also: M. Marody, "Homo Sovieticus and the Change of Values. The Case of Poland," in: Landmark 1989: Central and Eastern European societies twenty years after the system change, ed. H. Best and A. Wenninger, [Soziologie Forschung und Wissenschaft], Berlin: Lit, 2010, 80-89.

${ }^{21}$ S. H. Schwartz and A. Bardi, "Influences of Adaptation to Communist Rule on Value Priorities in Eastern Europe,” 18:2, 1997, doi:10.1111/0162-895X.00062.

${ }^{22}$ G. Schöpflin, "Identities, politics and post-Communism in Central Europe," Nations \& Nationalism 9:4, 2003. 
Thus, it should come as little surprise that trust between different levels of society continues to be an issue in post-communist Poland. Sztompka identifies resolving the conflict between private (personal) and public (official) spheres of life as the foundational problem facing countries readjusting to life after communism. This division is seen in several sets of opposites that follow an "us" versus "them" format: society versus authorities, nation versus the state, and the people versus rulers.

To illustrate the dichotomy of the post-communist value system, Sztompka borrows from Jeffery Alexander's binary discourses: the "discourse of real socialism" and the "discourse of emerging capitalism." ${ }^{23}$ From these binary discourses, several dimensions emerge. These dimensions, (a-g, explained below), show the tension between the cultural values people developed adapting to real socialism and the cultural values they will need to develop in order to adapt to democratic capitalism.

(a) Collectivism versus Individualism

Emerging capitalism requires taking risks and achieving personal success. Being recognized as an individual, one has more rights, but also more responsibilities.

(b) Private versus Public domain

Emerging democracy requires a commitment to the public domain and a willingness to participate in local and national discussions.

(c) Past versus Future

People tend to glorify the past and look to examples from "before the war". However, emerging capitalism requires innovation and planning for the future.

(d) Fate versus Human agency

Under real socialism, one was at the mercy of the state or other inaccessible, impersonal forces. On the other hand, democracy requires belief in the ability of the individual to effect change, both in his personal life and in the community.

(e) Liberty versus Consequentialism

Society rejected communism in terms of "freedom from" economic controls and Soviet influence (consequentialism). Emerging capitalism requires "freedom to" control and direct one's own life and governing institutions (liberty).

(f) Mythology versus Realism

Sztompka cites a "tendency to elevate mythical, religious, ideological thinking over mundane, realistic and rational arguments" to escape reality. Yet,

${ }^{23}$ J. C. Alexander, The Discourse of American Civil Society: A New Proposal for Cultural Studies, Los Angeles: UCLA (mimeo), 1989. 
a capitalist society requires "rationality" and a "cold calculation of profits and costs." 24

(g) Effectiveness versus Fairness:

The new society builds trust by universal adherence to law and contracts, irrespective of how instrumental it may seem at the time.

Sztompka comments that these biases, developed under the conditions of real socialism, still play an active role in society. Conversely, Civilizational competence, is achieved when a culture adopts the correct values above and represent the "historical achievement of modernity." 25

At the same time, it should be recognized that these dichotomies parallel the value dimensions presented by Trompenaars and Hampden-Turner. The culture rewarded in communist societies often, but not always, corresponds to one of the culture value orientations taken to the extreme. Table 1 juxtaposes Trompenaars and Hampden Turner's cultural value dimensions with Sztompka's observations regarding the post-communist society in Poland.

Table 1. Cultural Value Dimensions and Civilizational (In)Competencies

\begin{tabular}{|c|c|c|}
\hline $\begin{array}{l}\text { Cultural value } \\
\text { Dimension }\end{array}$ & $\begin{array}{c}\text { Negative aspects present in } \\
\text { Polish society }\end{array}$ & $\begin{array}{c}\text { Pre-requisites for success in } \\
\text { a capitalistic society }\end{array}$ \\
\hline $\begin{array}{l}\text { Universalism / } \\
\text { Particularism }\end{array}$ & $\begin{array}{l}\text { Particularism: Personal } \\
\text { connections are idealized; loyalty } \\
\text { to friends; authorities seen as } \\
\text { 'them'; solutions viewed in terms } \\
\text { of usefulness }\end{array}$ & $\begin{array}{l}\text { Universalism: political } \\
\text { activism; human rights for all } \\
\text { citizens; solutions measured } \\
\text { by a standard of right and } \\
\text { wrong }\end{array}$ \\
\hline $\begin{array}{l}\text { Individualism / } \\
\text { Communitarianism }\end{array}$ & $\begin{array}{l}\text { Communitarianism: "learned } \\
\text { helplessness"; reluctance to make } \\
\text { decisions or act outside the } \\
\text { group; pursuit of mediocrity } \\
\text { Individualism: Private life } \\
\text { demands a higher level of } \\
\text { integrity than public life }\end{array}$ & $\begin{array}{l}\text { Individualism: Taking risks; } \\
\text { achieving personal success; } \\
\text { individual competitiveness; } \\
\text { majority vote } \\
\text { Communitarian: healthcare }\end{array}$ \\
\hline
\end{tabular}

\footnotetext{
${ }^{24}$ P. Sztompka, "The intangibles and imponderables of the transition to democracy."

${ }^{25}$ P. Sztompka, "Civilizational Competence: A Prerequisite Of Post-communist Transition."
} 


\begin{tabular}{|c|c|c|}
\hline $\begin{array}{l}\text { Cultural value } \\
\text { Dimension }\end{array}$ & $\begin{array}{l}\text { Negative aspects present } \\
\text { in Polish society }\end{array}$ & $\begin{array}{l}\text { Pre-requisites for success } \\
\text { in a capitalistic society }\end{array}$ \\
\hline $\begin{array}{l}\text { Neutral / } \\
\text { Emotional }\end{array}$ & $\begin{array}{l}\text { Emotional: Myths received as } \\
\text { truth; elevation of ideological } \\
\text { thinking }\end{array}$ & $\begin{array}{l}\text { Neutral: Ideas accepted or } \\
\text { rejected on the basis of facts } \\
\text { alone; rational calculation }\end{array}$ \\
\hline Specific / Diffuse & $\begin{array}{l}\text { Diffuse: Expectation that } \\
\text { government/employer will } \\
\text { provide social benefits } \\
\text { Specific: Extreme } \\
\text { compartmentalization of public } \\
\text { and private life. }\end{array}$ & $\begin{array}{l}\text { Specific: scepticism and } \\
\text { criticism allowed and } \\
\text { encouraged }\end{array}$ \\
\hline $\begin{array}{l}\text { Achievement / } \\
\text { Ascribed Status }\end{array}$ & $\begin{array}{l}\text { Ascribed Status: Privileges based } \\
\text { on who one is and who one } \\
\text { knows; "disinterested envy" }\end{array}$ & $\begin{array}{l}\text { Achieved Status: ability of } \\
\text { a person to change status, } \\
\text { employment or salary } \\
\text { through hard work }\end{array}$ \\
\hline $\begin{array}{l}\text { Inward- / Outward- } \\
\text { Directed }\end{array}$ & $\begin{array}{l}\text { Outward-Directed: fatalism, } \\
\text { a feeling that one is unable to } \\
\text { change or control the future }\end{array}$ & $\begin{array}{l}\text { Inward-Directed: } \\
\text { Perseverance and personal } \\
\text { goals; belief in personal } \\
\text { ability to cause change }\end{array}$ \\
\hline $\begin{array}{l}\text { Sequential / } \\
\text { Synchronic Time }\end{array}$ & $\begin{array}{l}\text { Synchronic: inefficiency and } \\
\text { absenteeism in state jobs }\end{array}$ & $\begin{array}{l}\text { Sequential: orderliness, } \\
\text { punctuality }\end{array}$ \\
\hline $\begin{array}{l}\text { Past-, Present-, or } \\
\text { Future- Orientation }\end{array}$ & $\begin{array}{l}\text { Past-oriented: "before the war" } \\
\text { glorified }\end{array}$ & $\begin{array}{l}\text { Future-oriented: planning for } \\
\text { the future }\end{array}$ \\
\hline
\end{tabular}

Source: own study based on Trompenaars-Hampden-Turner and Sztompka.

The correlation between many of Sztompka's cultural (in)competencies and cultural value dimensions, could be cause for concern and imply that rushing to assimilate "capitalist" values may result in further disorientation. Even though Sztompka and others are acute in identifying the sociological dilemmas faced by post-communist societies, the solution they pose seems to reflect an American cultural value system without considering the uniqueness of other successful (European) cultural value orientations. ${ }^{26}$

${ }^{26}$ See M. J. King and J. O’Boyle, "Idea and Value Exchange Worldwide. American Culture in the World," Journal of American \& Comparative Cultures 25, 1-2, 2002, doi:10.1111/1542-734X.00001 for a list of American values that closely resembles Sztompka's pre-requisites for civilizational competence. 


\section{Suggestions for future research}

When originally compiling materials for this project, I was surprised by the limited amount of research that had been done into descriptive rather than evaluative culture studies in Central and Eastern Europe. While this is still unfortunately true, many surveys into societal trends and preferences are being conducted such as the European Values Survey and those organized by the Polish Public Opinion Research Center CBOS (Centrum Badania Opinii Społecznej). Sociologists have only begun to evaluate these results in light of cultural values. ${ }^{27}$ Much more could and should be done, both in descriptive and comparative analysis.

At the same time, comparative analysis must be done with caution. As seen by juxtaposing Trompenaars and Hampden-Turner's value dimensions with Sztompka’s requirements for civilizational competency, many Western neighbours would not make the cut as a "competent" capitalist country. Just as there is no single "right" culture, there is no single path to becoming a fully-functioning democracy. Just as each Western European culture developed independently and uniquely, so must each post-communist country be free to find itself under the layers of debris left by communism and previous occupations. ${ }^{28}$

Taking all of this into consideration, it becomes necessary to determine whether the dimensions identified by culture analysts to date are sufficient to describe the societies of Central and Eastern Europe. For this reason, further study into cultural values in Poland and other post-communist countries should be taken on by a team of scientists from mixed backgrounds, both inside and outside the countries where the research is being done. Because part of the solution lies in identifying cultural values present in Polish society before WWII, there is a need for sociologists to cooperate with scholars of Polish history and literature.

27 K. Baytchinska, "Values of Contemporary East European Culture. A Cross-Cultural and Developmental Approach," in: Political transformation and changing identities in central and eastern Europe, ed. A. M. Blasko and D. Januauskiene, Washington D.C.: Council for Research in Values and Philosophy, 2008, 299-322; M. Novojczyk, "Universalism versus Particularism through the European Social Survey Lenses," Acta Physica Polonica B 37:11, 2006.

28 E.g., T. Borén and M. Gentile, "Metropolitan Processes in Post-Communist States: an Introduction.," Swedish Society for Anthropology and Geography 89B:2, 2007; A. Matveeva, "Exporting Civil Society. The Post-Communist Experience," Problems of Post-Communism 55:2, 2008, doi:10.2753/PPC1075-8216550201. 
Identifying cultural patterns and tendencies in each country is a crucial step not only in rebuilding post-communist Europe, but also in dispelling the sense of inadequacy that seems to haunt contemporary society due to constant comparison with Western neighbours. Only by understanding the cultural values orientations and the reasoning behind them can effective steps be taken to improve cultural competence and to improve it in such a way that is not "Western" or foreign, but uniquely Polish. 